\title{
Immunoreactivity of the AAA+ chaperone ClpB from Leptospira interrogans with sera from Leptospira-infected animals
}

\author{
Joanna Krajewska ${ }^{1}$, Zbigniew Arent ${ }^{2}$, Daniel Więckowski ${ }^{1}$, Michal Zolkiewski ${ }^{3}$ and Sabina Kędzierska-Mieszkowska ${ }^{1 *}$
}

\begin{abstract}
Background: Leptospira interrogans is a spirochaete responsible for leptospirosis in mammals. The molecular mechanisms of the Leptospira virulence remain mostly unknown. Recently, it has been demonstrated that L. interrogans $\mathrm{ClpB}\left(\mathrm{ClpB}_{\mathrm{Li}}\right)$ is essential for bacterial survival under stressful conditions and also during infection. The aim of this study was to provide further insight into the role of ClpB in L. interrogans and answer the question whether $\mathrm{ClpB}_{\mathrm{Li}}$ as a potential virulence factor may be a target of the humoral immune response during leptospiral infections in mammals.

Results: $\mathrm{ClpB}_{\mathrm{Li}}$ consists of 860 amino acid residues with a predicted molecular mass of $96.3 \mathrm{kDa}$ and shows multi-domain organization similar to that of the well-characterized ClpB from Escherichia coli. The amino acid sequence identity between $C \mathrm{CpB}_{\mathrm{Li}}$ and $E$. coli $\mathrm{ClpB}$ is $52 \%$. The coding sequence of the $\mathrm{Clp} B_{L i}$ gene was cloned and expressed in E. coli BL21(DE3) strain. Immunoreactivity of the recombinant ClpB $B_{L i}$ protein was assessed with the sera collected from Leptospira-infected animals and uninfected healthy controls. Western blotting and ELISA analysis demonstrated that $\mathrm{ClpB}_{\mathrm{Li}}$ activates the host immune system, as evidenced by an increased level of antibodies against $\mathrm{ClpB}_{\mathrm{Li}}$ in the sera from infected animals, as compared to the control group. Additionally, $\mathrm{ClpB}_{\mathrm{Li}}$ was found in kidney tissues of Leptospira-infected hamsters.
\end{abstract}

Conclusions: $\mathrm{ClpB}_{\mathrm{Li}}$ is both synthesized and immunogenic during the infectious process, further supporting its involvement in the pathogenicity of Leptospira. In addition, the immunological properties of $\mathrm{ClpB}_{\mathrm{Li}}$ point to its potential value as a diagnostic antigen for the detection of leptospirosis.

Keywords: ClpB, Leptospira interrogans, Leptospirosis, Molecular chaperone, Pathogen

\section{Background}

Leptospira interrogans belongs to pathogenic spirochaetes causing a serious disease in both humans and animals known as leptospirosis that is considered the most widespread zoonosis of worldwide importance [1]. The vectors of this pathogen are mostly wild rodents and domestic animals, which harbor the spirochetes in the proximal renal tubules of the kidneys and chronically excrete the leptospires with urine into the environment [2]. It is worth noting that leptospirosis is also a serious economic problem, because it causes abortions, stillbirths, infertility, failure to thrive, reduced milk production, and death in domestic

\footnotetext{
* Correspondence: sabina.kedzierska-mieszkowska@biol.ug.edu.pl 'Department of General and Medical Biochemistry, University of Gdansk, Faculty of Biology, 80-308 Gdańsk, Poland

Full list of author information is available at the end of the article
}

animals such as cows, pigs, sheep, goats, horses and dogs [3-6]. In humans the disease varies from an asymptomatic flu-like illness to an acute life-threatening infection. Despite its severity and global importance, the molecular mechanisms of leptospiral pathogenesis remain largely unknown [1]. To date, only a few proteins have been identified as potential virulence factors in Leptospira. Among them, there is the chaperone ClpB, a member the Hsp100/ Clp subfamily of the AAA+ ATPases that reactivates stress-aggregated proteins in cooperation with the DnaK system [7]. Recently, $\mathrm{ClpB}$ from L. interrogans $\left(\mathrm{ClpB}_{\mathrm{Li}}\right)$ has been shown to be essential for bacterial survival under stressful conditions (nutrient restriction, oxidative and heat stresses) and also for the pathogen's virulence [8]. The involvement of $\mathrm{ClpB}$ in the response of L. interrogans to oxidative stress suggests that this chaperone may be 
one of key mediators of stress resistance, which is a prerequisite for Leptospira pathogenesis. The present study provides further insight into the role of $\mathrm{ClpB}_{\mathrm{Li}}$ during the infectious process. It is known that heat shock proteins (Hsps) play important roles during bacterial infections. They help pathogens to overcome stressful conditions to which they are exposed within the host cells, and represent major targets of the host's immune system. Taking into account the fact that the chaperone $\mathrm{ClpB}$ from some pathogenic bacteria, Francisella tularensis and Mycoplasma pneumoniae, has been shown to be immunoreactive $[9,10]$, we decided to investigate an immunogenic potential of $\mathrm{ClpB}_{\mathrm{Li}}$, which could point to this chaperone's role in the pathogenicity of Leptospira and may translate into diagnostic applications.

\section{Methods}

\section{Serum samples}

We studied archived serum samples from rabbits and cattle. Rabbit antisera $(n=8)$ against $L$. interrogans serovars: Icterohaemorrhagiae, Hardjo, and Canicola, and $L$. borgpetersenii serovars: Hardjo, Javanica, were prepared as described by [11]. Polyclonal rabbit antiserum prepared against the $L$. interrogans $\mathrm{ClpB}$ (residues 158-334;

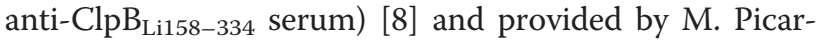
deau was used as a positive control and the pre-immune serum was used as a negative control. Bovine sera were collected from cattle $(n=10)$ experimentally infected with L. borgpetersenii serovar Hardjo via conjunctival instillation of $1 \times 10^{6}$ bacteria. Blood samples were collected 28 days after the challenge and in one case 210 days after the challenge (this serum was used as a positive control showing the highest OD in ELISA). Sera from uninfected cattle $(n=8)$ and also a fetal bovine serum were used as negative controls. To confirm the serological status of leptospiral infection, the sera were subjected to the microscopic agglutination test (MAT) [11, 12] and used at dilutions 1:100 for Western blotting or 1:200 for ELISA.

\section{Kidney homogenate preparation}

For detection of $\mathrm{ClpB}_{\mathrm{Li}}$ in kidney tissues from Leptospira-infected hamsters, the kidneys were macerated with nine parts of a $1 \%$ BSA diluent and inoculated into Tween80/40/ LH semi-solid medium. Cultures were incubated at $28-30{ }^{\circ} \mathrm{C}$, for up to 10 weeks and examined weekly by dark-field microscopy to detect the growth of leptospires. The same macerated kidney tissues $(20 \mu \mathrm{g}$ sample of homogenate) were used for Western-blotting analysis. Total protein concentration in the homogenates was determined by the method of Bradford [13].

\section{Plasmid construction for protein overproduction}

L. interrogans clpB gene (2583 bp) was amplified from genomic DNA of L. interrogans by PCR using AccuTaq
LA polymerase MIX (Sigma) with the following primers: CATATGAAATTAGATAAACTTACATCCAAATT with the NdeI restriction site underlined, and AAGCTTT TAAACTACAACAACTACC with the HindIII restriction site underlined. DNA primers were synthesized by Genomed S.A. (Warsaw, Poland). First, the PCR product was cloned into pJET1.2 blunt vector (Fermentas), then digested with NdeI, HindIII, and ligated with the linearized pET NdeI-HindIII vector. The sequence of the resulting construct was confirmed by DNA sequencing (Genomed S.A.). Leptospira genomic DNA was extracted with a QIAamp DNA Mini Kit (Qiagen).

DNA plasmid preparation and transformation of $E$. coli cells were done according to [14].

\section{Purification of the recombinant $\mathrm{ClpB}_{\mathrm{L}}$}

L. interrogans $\mathrm{ClpB}$ protein was overproduced in E. coli BL21(DE3) strain (Novagen) and purified according to the procedure similar to that used to obtain ClpB from Ehrlichia chaffeensis [15]. Briefly, bacteria were grown at $37{ }^{\circ} \mathrm{C}$ to $\mathrm{OD}_{600}=0.6$ and then induced with $0.5 \mathrm{mM}$ IPTG for $2 \mathrm{~h}$. Next, the cells were collected and suspended in $50 \mathrm{mM}$ Tris- $\mathrm{HCl}(\mathrm{pH} 7.4), 300 \mathrm{mM} \mathrm{NaCl}, 20 \mathrm{mM}$ imidazole and $0.1 \%$ Triton X-100, then disrupted by sonication in the presence of the protease inhibitor PMSF and centrifuged to collect the soluble extract. Next, polyethyleneimine (PEI) was added to precipitate nucleic acids. After centrifugation $(20000 \mathrm{~g}, 1 \mathrm{~h})$, the supernatant was applied to a Ni-NTA column (Qiagen) and the bound protein was eluted with $50 \mathrm{mM}$ Tris- $\mathrm{HCl}$ (pH 7.4), $300 \mathrm{mM} \mathrm{NaCl}$, and $0.1 \%$ Triton X-100 and $250 \mathrm{mM}$ imidazole. Fractions containing a 6 His-tagged $\mathrm{ClpB}_{\mathrm{Li}}$ (a calculated molecular mass of $98488.59 \mathrm{Da}$ ) were identified with SDS-PAGE electrophoresis and Coomassie blue staining, then combined and further purified by gel filtration on Superdex 200 (Sigma) equilibrated with $50 \mathrm{mM}$ Tris- $\mathrm{HCl}$ (pH 7.5), $10 \%$ glycerol, $1 \mathrm{mM}$ EDTA and $1 \mathrm{mM}$ DTT. The pooled fractions containing $\mathrm{ClpB}_{\mathrm{Li}}$ were dialyzed against dialysis buffer (50 mM Tris- $\mathrm{HCl} \mathrm{pH} 7.5,1 \mathrm{mM}$ EDTA, $1 \mathrm{mM}$ DTT, $20 \mathrm{mM} \mathrm{MgCl} 2,200 \mathrm{mM} \mathrm{KCl}, 10 \%$ glycerol) and stored at $-70{ }^{\circ} \mathrm{C}$. The $\mathrm{N}$-terminal histidine tag was removed by proteolytic digestion using the Thrombin Cleavage Capture Kit (Novagen) according to the manufacturer's protocol. The identity of the purified $\mathrm{ClpB}_{\mathrm{Li}}$ was confirmed by a liquid chromatography-tandem mass spectrometry (LC-MS/MS) analysis of tryptic peptides obtained after trypsin cleavage of the protein, performed at the MS LAB IBB PAN (Warsaw, Poland). The equipment used was sponsored in part by the Centre for Preclinical Research and Technology (CePT), a project co-sponsored by European Regional Development Fund and Innovative Economy, The National Cohesion Strategy of Poland. 
SDS-PAGE and Western blotting analysis

To assess immune reactivity of $\mathrm{ClpB}_{\mathrm{Li}}$, SDS-PAGE electrophoresis was performed according to [16] using $10 \%$ polyacrylamide gels and Western blotting was performed as described [17]. The blots were blocked with $0.1 \%$ Tween 20 in Tris-buffered saline (TBS) for $1 \mathrm{~h}$ at room temperature and then incubated overnight at $4{ }^{\circ} \mathrm{C}$ with

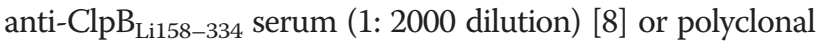

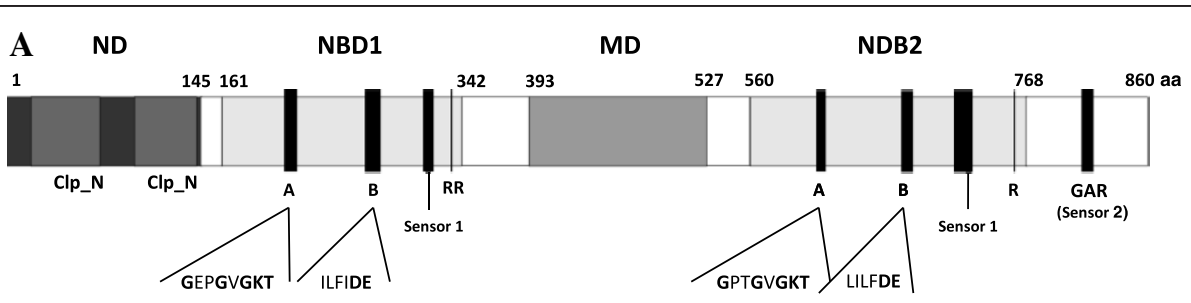

$\mathbf{B}$

BEC 1 MRLDRLTNKFQLALADAQSLALGHDNQFIEPLHLMSALLNQEGGSVPLLTSAGINAGQI BLi 1 MKLDKLTSKLNEAIYNAQASAEKLGNPEISEEHILKEVLSQPDGLVPLLISKLNLSPKSF BEC 61 RTDINQALNRLPQVEGTG-GDVQPSQDIVRVLNLCDKLAQKRGDNFISSELFVLAALESR $B_{L i} 61$ LESTENALGKQPKVGGN SADVGFSRSAVSLLKAADEVRKELKDEYISTDHILLGLMKNG

BEC 120 GT-LADILKAAGATTANITQAIEQMRGGESVNDQGAEDQRQALKKYTIDLTERAEQGKLD BLi 121 TGSLKTEFLKLGLEYHKLLKITLENRKGKTIM DSPEGKTDALAKYAKNLNELAKQGKLD ND $\quad->>-$ linker-->-- NBD1

BEC 179 PVIGRDEEIRRTIQVLQRRTKNNPVLIGEPGVGKTAIVEGLAQRIINGEVPEGLKGRRVL BLi 181 PVIGRDEEIRRTIQVLSRRTKNNPVLIGEPGVGKTAIVEGLANKIVOGEVPEGIKNKTLY

BEC 239 ALDMGALVAGAKYRGEFEERLKGVLNDLAKQEGNVILFIDELHTMVGAGKADGAMDAGNM

$B_{L i} 241$ TLDLGSMIAGAKYRGEFEDRLKAILDEVKSSDGEVILFIDW IHTLVGAGATEGALDASNM

BEC 299 LKPALARGELHCVGATTLDEYRQY IEKDAALERRFQKVFVAEPSVEDTIAILRGLKERYF

B 301 LKPMLARGEIRCIGATTIKEYQKYIEKDAALERRFQPVYVKEPSVEFTVTILRGLKGRYE NBD1 sensor 1

BEC 359 LHHHVQITDPAIVAAATLSHRYIADRQLPDKAIDLIDEAASSIRMQIDSKPEELDRLDRR BLi 361 LHHGIRILDSAI IAAATLSNRY I SDRFLPDKAVDLIDEASSKMRIEIDSMPEELDRANKR BEC 419 I IQLKLEQQALMKESDEASKKRLDMLNEELSDKERQYSELEEEWKAEKASLSGTQT IKAE B 421 IQSLKIEREALKKEQDTASKERLKTLERDLSEQEQNEQTLKARWDLEKSKIGRLKOIKEE BEC 479 LEQAKIAIEQARRVGDLARMSELQYGKIPELEKQLEAATQLEGKT- - MRLLRNKVTDAF $B_{L i} 481$ IEKYKNLEAEAERRGE INRVAEIRYGKLVDLEKELESANEELKKQESASRLLKEEVSEED BEC 536 IAEVLARWTGIPVSRMMESEREKLLRMEQELHHRVIGQNEAVDAVSNAIRRSRAGLADPN

B 541 IANIVSRWTGIPVSKMLQGERAKLLLMEDVLKTKVIGQDHALRLVSEAVQRSRAGIADPN $--><--$ NBD2

BEC 596 RPIGSFLFLGPTGVGKTELCKALANFMFDSDEAMVRIDMSEFMEKHSVSRLVGAPPGYVG

B 601 RPIGTFLFLGPTGVGKTETAKALAEFLFDDVNAMTRIDMSEYMEAHSVARLIGAPPGYVG Balker $A$ A 656 YEEGGYLTEAVRRRPYSVIILDEVEKAHPDVFNILLQVLDDGRLTDGQGRTVDFRNTVV $B_{L i} 661$ YDEGGQLTEAVRRRPYSIILFDEIEKANPEVFNIFLQILDEGRLTDGKGRNVDFKNTVII
WaIker B

$B_{E C} 716$ MTSNLGSDLIQERFGELDYAHM-KELVLG---------VVSHNFRPEFINRIDEVVVFHP

$B_{\mathrm{Li}} 721$ LTSNIGS----EILGS SEYTSEEKERLVEQR-------LKKHFKPEFLNRIDEVILFHS
sensor 1 BEC 766 LGE QHIAS IAQIQLKRLYKRLEERGYEIHISDEALKLLSENGYDPVYGARPLKRAIQQQI $\mathrm{B}_{\mathrm{Li}} 769$ I DSV HKIADIQLEG RQKAK NG DV FTN L DYV KAGEAEYGARPLKRLIQREV $\begin{array}{lll}B_{E C} & 826 & \text { ENPLAQQILSGELVPG-KVIRLEVNEDRIVAVQ } \\ B_{L i} & 829 & \text { GNALSRYILDGKFTNGQNVTVDYRQGKVVVVV- }\end{array}$

Fig. 1 Proposed domain organization of ClpB from L. interrogans. a The diagram shows structural domains of the protein: N-terminal domain (ND) with the double Clp_N motif, nucleotide binding domain 1 (NBD1), middle coiled-coil domain (MD) and nucleotide binding domain 2 (NBD2). Conserved ATPase motifs such as the Walker A (A), Walker B (B), sensor 1, sensor 2 (GAR) and the Arg fingers (R), coordinating ATP binding and hydrolysis are also indicated. Conserved residues of these motifs are marked in bold. b Sequence alignment of ClpB from E. coli ( $\left.B_{E C}\right)$ and $L$. interrogans $\left(\mathrm{B}_{\mathrm{L}}\right)$. Domain boundaries are indicated below the amino acid sequence. The conserved motifs are shown in red. Identical and similar amino acid resides are shaded in black and gray, ... respectively 
rabbit and bovine sera (1:100 dilution) against Leptospira strains. After primary antibody incubation, the blots were washed three times with TBS containing $0.05 \%$ Tween 20 and incubated for $1 \mathrm{~h}$ at room temperature with the goat anti-rabbit IgG horseradish peroxidase (HRP) conjugate (Sigma) diluted 1: 3000 or the polyclonal rabbit anti-cow Ig/HRP conjugate (DakoCytomation) diluted 1: 1000. The blots were then washed three times as described above and were developed using 3,3'-diaminobenzidine (Sigma), and $\mathrm{H}_{2} \mathrm{O}_{2}$ as substrates.

\section{ELISA procedure}

ELISA (enzyme-linked immunosorbent assay), was performed to analyze the immune response in animals experimentally exposed to $L$. interrogans serovars. Costar 96 well EIA/RIA polystyrene high-binding plates were coated with $100 \mu \mathrm{l}$ of $0.625 \mu \mathrm{g} / \mathrm{ml}$ of the recombinant $\mathrm{ClpB}_{\mathrm{Li}}$ (a capture antigen) resuspended in phosphate-buffered saline (PBS) by incubation overnight at $4{ }^{\circ} \mathrm{C}$. The plates were then washed five times with PBST buffer (PBS containing $0.05 \%$ Tween 20) and non-specific binding sites were blocked by incubation with $100 \mu \mathrm{l}$ of $0.1 \%$ Tween 20 in PBS buffer for $1 \mathrm{~h}$ at room temperature. The wells were washed five times with PBST buffer. Control and duplicate animal serum samples were diluted 200-fold in PBST buffer and $50 \mu \mathrm{l}$ of the diluted sera (in duplicate) were applied to each well and incubated at $37^{\circ} \mathrm{C}$ for $1 \mathrm{~h}$, followed by five rinses with PBST buffer. Next, secondary HRP-conjugated anti-rabbit (Abcam) (diluted 1:10 000) or anti-cow IgG (DakoCytomation) (diluted 1:2000) were added to each well and incubated for $1 \mathrm{~h}$ at $37^{\circ} \mathrm{C}$. The plates were then washed five times with PBS buffer and 3,3',5,5'-tetramethylbenzidine (TMB) (Sigma-Aldrich) was added to detect the antibodies. The reaction was stopped after $10 \mathrm{~min}$ by the addition of $50 \mu \mathrm{l}$ of $1 \mathrm{M} \mathrm{H}_{2} \mathrm{SO}_{4}$. The absorbance at $450 \mathrm{~nm}$ was measured using PerkinElmer Multimode Plate Reader (Enspire). The assay was performed three times for each serum.

\section{Data analysis}

The statistical significance of differences between the ELISA results obtained for sera collected from uninfected and infected animals were determined using the Welch's adjusted one-way ANOVA followed by the post-hoc Scheffe multiple comparison test. $P<0.05$ was considered statistically significant. Results of data analysis are presented in the graphs as the median values. All statistical analyses were performed using STATISTICA PL program.

\section{Results}

Analysis of the amino-acid sequence of the molecular chaperone ClpB from L. interrogans

The $c l p B_{L i}$ gene encodes a protein of 860 amino acid residues with a predicted molecular mass of 96325.2 Da.
Sequence alignment of $\mathrm{ClpB}_{\mathrm{Li}}$ (Fig. 1) revealed that this protein shows a multi-domain organization similar to that of the well-characterized $\mathrm{ClpB}$ from Escherichia coli $\left(\mathrm{ClpB}_{\mathrm{Ec}}\right)$. Thus, $\mathrm{ClpB}_{\mathrm{Li}}$ contains an $\mathrm{N}$-terminal domain $\left(\mathrm{ND}_{1-145 \mathrm{aa}}\right)$, two nucleotide binding domains (NBD1 161-342aa, NBD2 $\left.{ }_{560-768 a a}\right)$ and a middle coiled-coil domain $\left(\mathrm{MD}_{393-527 a a}\right)$ (Fig. 1). Both NBDs, involved in ATP binding and ATP hydrolysis, contain all characteristic and conserved sequence mofits of AAA+ ATPases (ATPases associated with a variety of cellular activities), i.e. Walker A $\left(\mathrm{GX}_{4} \mathrm{GKT} / \mathrm{S}\right)$, Walker B $\left(\mathrm{Hy}_{2} \mathrm{DE}\right)$ and sensor $1 / 2$ motifs. Conserved arginine residues called Arg fingers are also present in both NBD domains. Sequence alignment of the ClpB sequences from bacteria $L$. interrogans and E. coli using the Clustal software revealed that the total sequence identity between them is only $52 \% ; 27.7 \%$ within ND, $45.3 \%$ within MD, $72 \%$ within NBD1, and $65.7 \%$ within NBD2. Therefore, the most highly conserved are the NBD domains and the main differences between $L$. interrogans and E. coli $\mathrm{ClpB}$ are in the N-terminal domain and the coiled-coil middle domain.

\section{Expression of the $c / p B_{L i}$ gene in E. coli cells and purification of $\mathrm{ClpB}_{\mathrm{Li}}$}

To examine whether $\mathrm{ClpB}_{\mathrm{Li}}$ shows an immunogenic potential, which could point to its participation in the pathogenicity of Leptospira, we obtained a construct expressing $\operatorname{clp} B_{L i}\left(\mathrm{pET} 28 c l p B_{L i}\right)$ and then overproduced the recombinant $\mathrm{ClpB}_{\mathrm{Li}}$ as a 6-histidine-tagged protein in E. coli B21(DE3) cells. As expected, the expression of $\mathrm{pET} 28 \mathrm{clp} B_{L i}$ resulted in the $\sim 100-\mathrm{kDa}$ protein,

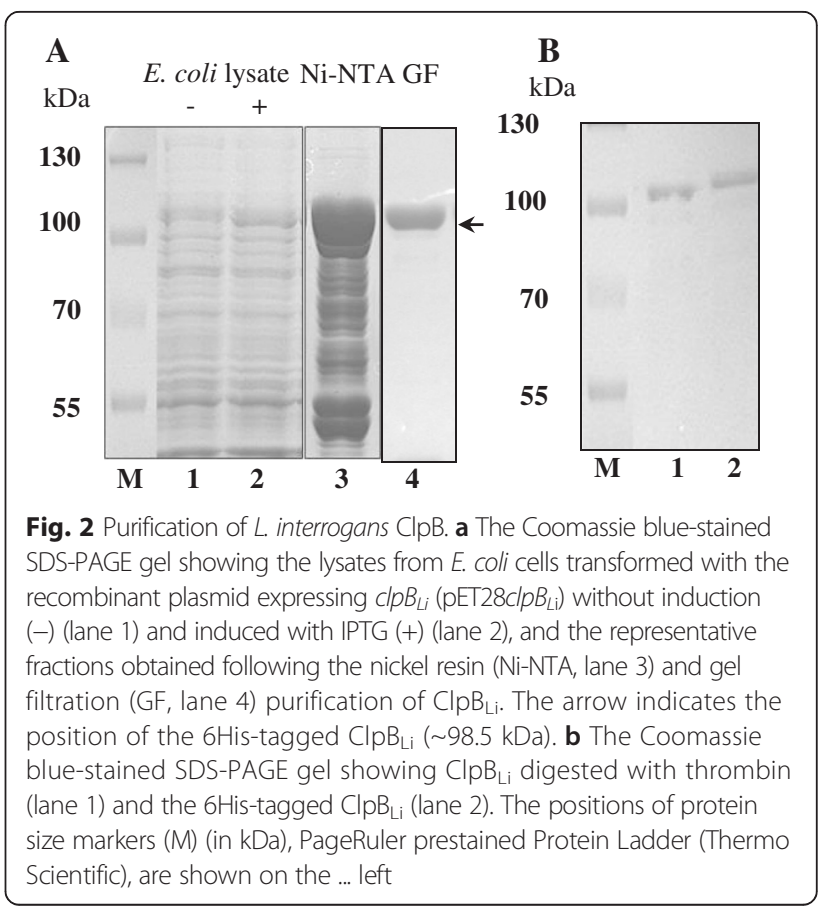




\section{Protein sequence coverage: $\mathbf{8 8} \%$}

1 MKLDKLTSKL NEAIYNAQAS AEKLGNPEIS EEHILKEVLS QPDGLVPLLI

51 SKLNLSPKSF LESTENALGK QPKVGGNTSA DVGFSRSAVS LLKAADEVRK 101 ELKDEYLSTD HILLGLMKNG TGSLKTEFLK LGLEYHKLLK ITLENRKGKT 151 IMDDSPEGKT DALAKYAKNL NELAKQGKLD PVIGRDEEIR RTIQVLSRRT 201 KNNPVLIGEP GVGKTAIVEG LANKIVQGEV PEGIKNKTLY TLDLGSMIAG 251 AKYRGEFEDR LKALLDEVKS SDGEVILFID EIHTLVGAGA TEGALDASNM 301 LKPMLARGEL RCIGATTLKE YQKYIEKDAA LERRFQPVYV KEPSVEETVT 351 ILRGLKGRYE LHHGIRILDS ALIAAATLSN RYISDRFLPD KAVDLIDEAS 401 SKMRIEIDSM PEELDRANKR IQSLKIEREA LKKEQDTASK ERLKTLERDL 451 SEQEQNFQTL KARWDLEKSK IGRLKQIKEE IEKYKNLEAE AERRGEINRV 501 AEIRYGKLVD LQKELESANE ELKKQESASR LLKEEVSEED IANIVSRWTG 551 IPVSKMLQGE RAKLLLMEDV LKTKVIGQDH ALRLVSEAVQ RSRAGIADPN 601 RPIGTFLFLG PTGVGKTETA KALAEFLFDD VNAMTRIDMS EYMEAHSVAR 651 LIGAPPGYVG YDEGGQLTEA VRRRPYSLIL FDEIERANPE VFNIFLQILD 701 EGRLTDGKGR NVDFKNTVII LTSNIGSEIL GSSEYTSEEK ERLVEQRLKK 751 HFKPEFLNRI DEVILFHSIT DSVIHKIADI QLEGLRQKAK ENGLDVSFTN 801 ELKDYVSKAG FDAEYGARPL KRLIQREVGN ALSRYILDGK FTNGQNVTVD 851 YRVQGKVVVV

Fig. 3 LC-MS/MS analysis of the purified $C l p B_{L}$. The amino acid sequence of $\mathrm{ClpB}_{\mathrm{L}}$ is shown with the peptides detected by LC-MS/MS indicated in ... red

A

$\mathrm{kDa}$

Controls L. interrogans L. borgpetersenii

130 M positive/negative/Hardjo/Icterohaemorrhagiae/Canicola/Hardjo/Hardjo/ Hardjo/Javanica 100

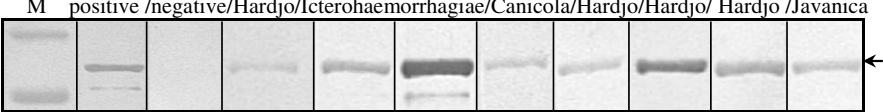

B

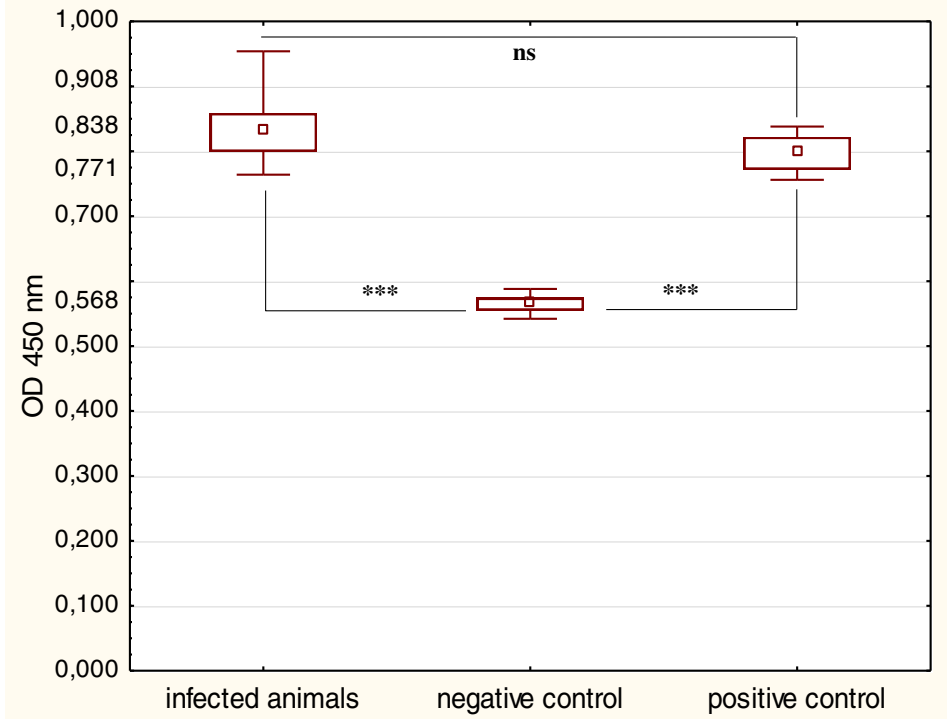

Fig. 4 Immune reactivity of the recombinant $C_{\text {IpB }}$ with rabbit sera. a The purified $C l p B_{L i}$ protein $(250 \mathrm{ng})$ was resolved by SDS-PAGE and

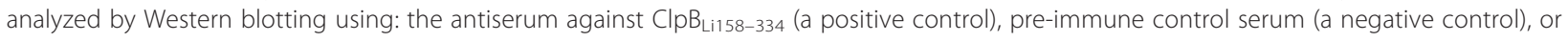
polyclonal rabbit antisera raised against: L. interrogans and L. borgpetersenii serovars as indicated in the figure. The positions of protein size markers (M) (in kDa), PageRuler prestained Protein Ladder (Thermo Scientific), are shown on the left. The arrow indicates the position of $\mathrm{ClpB}_{\mathrm{Li}}$. (b) ELISA analysis of the recombinant $\mathrm{ClpB}_{\mathrm{Li}}$ protein as a capture antigen using all the above rabbit sera. The data were analyzed using Welch adjusted one-way ANOVA. Symbols: ( $)$, the median value; (box), $25 \%-75 \%$ range around the median value; (whiskers), min-max range. ${ }^{* * *}$ ) denotes $P<0.001$; ns, not statistically significant 
corresponding to $\mathrm{ClpB}_{\mathrm{Li}}$ that was soluble in E. coli cells. The protein was purified from the soluble fraction using two separation techniques: immobilized metal affinity chromatography (IMAC) and gel filtration chromatography (Fig. 2a). The identity of $\mathrm{ClpB}_{\mathrm{Li}}$ was confirmed with an LC-MS/MS analysis (Fig. 3). The obtained peptide map covered $88 \%$ of the amino acid sequence of $\mathrm{ClpB}_{\mathrm{Li}}$. In addition, LC-MS/MS data indicated that the purified $\mathrm{ClpB}_{\mathrm{Li}}$ was not contaminated with $\mathrm{ClpB}$ from the E. coli host strain. The purified $\mathrm{ClpB}_{\mathrm{Li}}$ was subsequently digested with thrombin to remove the N-terminal 6His-tag (Fig. 2b). The post-cleavage $\mathrm{N}$-terminal sequence of the recombinant $\mathrm{ClpB}_{\mathrm{Li}}$ protein contains three additional amino acid residues, namely GlySerHis, and in such form the protein was further characterized by Western blotting analysis and ELISA assay.

\section{Immunogenic capacity of $\mathrm{ClpB}_{\mathrm{Li}}$}

The immune reactivity of $\mathrm{ClpB}_{\mathrm{Li}}$ with serologically positive sera from rabbits and cattle experimentally infected with two pathogenic Leptospira species (L. interrogans and $L$. borgpetersenii) was tested by Western blotting (Figs. 4a and 5a) and ELISA assay (Figs. 4b and 5b) and compared to the sera from uninfected healthy controls. We found that all the tested sera prepared from Leptospirainfected animals, but not from the uninfected controls,

A $\mathrm{kD}$
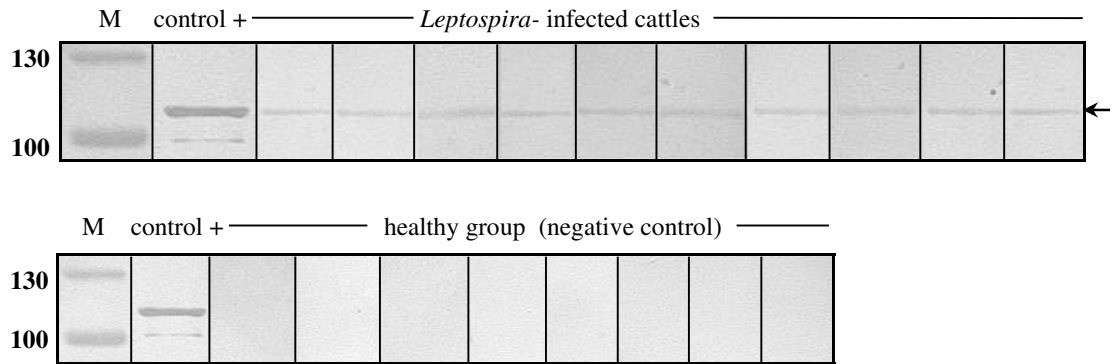

B

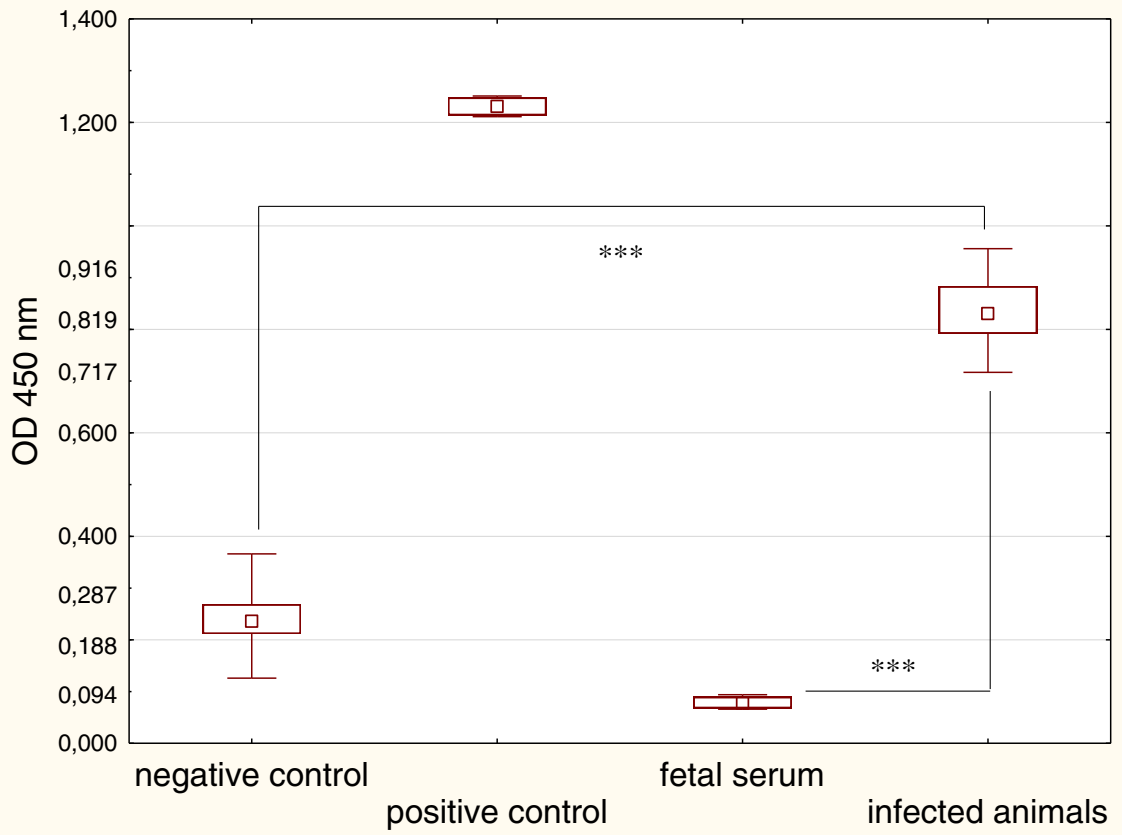

Fig. $5 \mathrm{Immune}$ reactivity of the recombinant $\mathrm{ClpB}_{\mathrm{Li}}$ with bovine sera. a The purified $\mathrm{ClpB}_{\mathrm{Li}}$ protein $(250 \mathrm{ng})$ was resolved by SDS-PAGE and analyzed by Western blotting using the antiserum against $\mathrm{Cl}_{\mathrm{PB}} \mathrm{L}_{\mathrm{Li158-334}}$ (a positive control; control +), polyclonal bovine antisera raised against: L. borgpetersenii serovar Hardjo (Leptospira-infected cattle), and sera collected from uninfected cattle (healthy group; negative control). The positions of protein size markers (M) (in kDa), PageRuler prestained Protein (Thermo Scientific), are shown on the left. The arrow indicates the position of ClpB $B_{\mathrm{Li}}(\sim 100-\mathrm{kDa})$. b ELISA analysis of the recombinant $\mathrm{ClpB}_{\mathrm{Li}}$ protein as a capture antigen using the above bovine sera. Fetal bovine serum was also used. The data were analyzed using Welch adjusted one-way ANOVA. Symbols: (a), the median value; (box), 25 \%-75 \% range around the median value, (whiskers), min-max range. $\left.{ }^{* * *}\right)$ denotes $P<\ldots .0001$ 
strongly reacted with $\mathrm{ClpB}_{\mathrm{Li}}$ in Western blotting (Figs. 4a, 5a). The ELISA signals of the sera from infected animals were also significantly higher than those of uninfected animals (Figs. 4b, 5b; $P<0.001$ ). These results show that Leptospira infection induces production of anti$\mathrm{ClpB}_{\mathrm{Li}}$ antibodies in animal models. The cross-reactivity between $L$. interrogans and $L$. borgpetersenii is not surprising due to $\sim 95 \%$ sequence similarity between $\mathrm{ClpB}$ from those two species [8].

\section{Detection of $\mathrm{ClpB}_{\mathrm{Li}}$ in Leptospira-infected animals}

Additionally, we detected $\mathrm{ClpB}_{\mathrm{Li}}(96-\mathrm{kDa}$ protein) in the infected hamster kidney tissue (Fig. 6), from which leptospires were isolated using standard culture method. No reactivity of the $96-\mathrm{kDa}$ protein with anti-ClpB $\mathrm{L}_{\mathrm{Li158-334}}$ serum was observed in the kidney homogenate obtained from an uninfected hamster (Fig. 6, lane 4). The result indicates that $\mathrm{ClpB}_{\mathrm{Li}}$, is produced during an experimental infection of animals.

In summary, our data indicate that the molecular chaperone $\mathrm{ClpB}_{\mathrm{Li}}$ is immunogenic and detectable in animals infected with pathogenic Leptospira spp.

\section{Discussion}

Leptospires like many other pathogenic bacteria are exposed to a significant stress during infection of host cells, frequently resulting in protein misfolding and aggregation. Despite being exposed to stressful conditions, pathogens survive, overcome host defense mechanisms, and cause the disease symptoms. The specific mechanisms of the host invasion by leptospires are not well defined. In particular, the molecular basis for virulence remains unknown, due to the lack of genetic tools for the manipulation of Leptospira. The fact that $\mathrm{ClpB}$ is usually up-regulated in pathogenic microorganisms $[8,15]$ suggests that the disaggregase activity of $\mathrm{ClpB}$ may be essential for their virulence. Moreover, the involvement

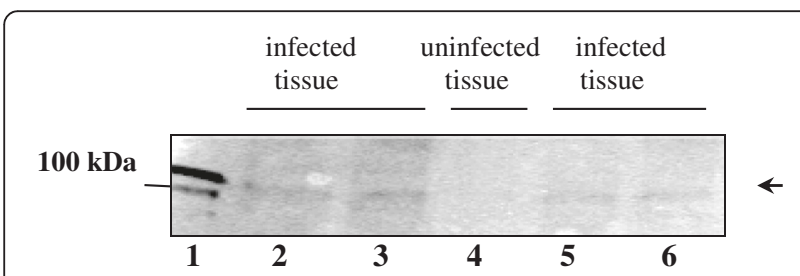

Fig. 6 Detection of $\mathrm{ClpB}_{\mathrm{Li}}$ in hamster kidney tissues. The macerated kidney tissues containing $\sim 20 \mu \mathrm{g}$ proteins were subjected to SDS-PAGE

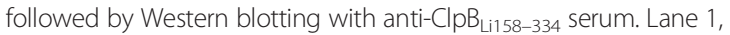
purified $\mathrm{ClpB}_{\mathrm{Li}}$ (a positive control); lanes 2, 3, 5, 6, the kidney homogenates from hamsters infected with $L$. interrogans serovar Hardjo and euthanized 14 (lane 2) or 6 (lanes: 3,5,6) weeks post infection; lane 4, the kidney homogenate from an uninfected hamster. The arrow indicates the position of the 6 His-tagged $\mathrm{ClpB}_{\mathrm{Li}}(\sim 98.5 \mathrm{kDa})$. The position of 100-kDa protein marker (PageRuler unstained Protein Ladder; Thermo Scientific), is shown on the ... left of $\mathrm{ClpB}$ in the response of $L$. interrogans to oxidative stress [8] suggests that this chaperone may be one of key mediators of stress resistance, which is a prerequisite for Leptospira pathogenesis. The chaperone $\mathrm{ClpB}$ may function either as a true virulence factor directly involved in causing the disease or a virulence-associated protein that can be essential for colonization of the host. Virulence gene products are often immunogenic and responsible for acquired immunity that protects against disease [18]. At this point it should be also noted that molecular chaperones despite their cytosolic localization are strongly immunogenic in a number of bacterial infections [19]. It has been reported that some chaperones (e.g. GroEL) may be associated with the outer membrane of the pathogenic bacteria or exported from the bacterial cell after heat shock [19]. Therefore, exposure of bacterial Hsps to the host's immune system is possible during infection. Indeed, ClpB from some pathogens (i.e. Mycoplasma pneumoniae, Francisella tularensis) is an immunoreactive protein [9, 10]. The total sequence identity between $\mathrm{ClpB}$ proteins from these pathogens is only $\sim 40 \%$. It is likely that $\mathrm{ClpB}$ as an important mediator of resistance to oxidative stress could be also a potential target for the host immune response during leptospiral infections in mammals. Therefore, we decided to investigate an immunogenic potential of this chaperone in Leptospira. The use of the E. coli expression system allowed us to produce the recombinant $\mathrm{ClpB}_{\mathrm{Li}}$ protein and to assess its immune reactivity with sera collected from Leptospira-infected animals and the uninfected healthy controls. Our results show that ClpB is immunogenic during leptospiral infections because it was recognized by sera collected from experimentally infected animals (see Figs. 4 and 5). Thus, among the antibodies raised against leptospiral proteins, there were specific antibodies against $\mathrm{ClpB}_{\mathrm{Li}}$. This is the first study where $\mathrm{ClpB}$ from pathogenic Leptospira species was evaluated for its ability to elicit immune responses in animals. Moreover, our results suggest that $\mathrm{ClpB}_{\mathrm{Li}}$ could be considered as a potential antigen candidate for a diagnostic test. We postulate that the presence of species-specific domains (e.g. ND or MD, see Fig. 1) in the antigen could minimize a cross-reactivity of antibodies with $\mathrm{ClpB}$ from different bacteria. Further prospective studies are needed to assess the $\mathrm{ClpB}_{\mathrm{Li}}$ 's predictive value in leptospirosis diagnostics. In addition, the presence of $\mathrm{ClpB}_{\mathrm{Li}}$ in the infected hamster kidney tissues (see Fig. 6) demonstrates that the chaperone is produced by pathogen during infection of the host further confirming the involvement of $\mathrm{ClpB}$ in the pathogenicity of Leptospira.

\section{Conclusions}

Identification of Leptospira virulence factors and understanding their properties is crucial for uncovering the diseases mechanisms. This study underlines the potential 
importance of the chaperone $\mathrm{ClpB}$ in leptospiral infections. We believe that our data provide new information, which may lead to a better understanding of the role of $\mathrm{ClpB}$ and possibly other stress-response factors in the life cycle of the pathogenic bacterium $L$. interrogans. It is worth noting that since $\mathrm{ClpB}$ does not exist in animal cells, it might become a promising target for novel therapies against pathogenic Leptospira species. Further studies are needed to determine the biological role of $\mathrm{ClpB}$ during leptospiral infection in mammals and its diagnostic or even immunoprotective potential. The recombinant $\mathrm{ClpB}_{\mathrm{Li}}$ produced in this work will help in further biochemical characterization of this chaperone and the analysis of its function in the pathogen.

\section{Acknowledgements}

We thank M. Picardeau (Institut Pasteur, Unité de Biologie des Spirochètes) for the generous gift of $\mathrm{ClpB}_{\mathrm{Li}}$ antiserum. We are very grateful to $\mathrm{S}$. Barańska (University of Gdańsk) for her excellent assistance in the statistical analyses.

\section{Funding}

This work was supported by the Preludium Grant number 2015/17/N/NZ6/ 03493 (to JK) from the National Science Center (Poland).

\section{Availability of supporting data}

The DNA sequence of $L$. interrogans CIDB gene was retrieved from the EMBL-EBI (accession number AAS70592.1) website (http://www.ebi.ac.uk/ena/data/view/ AAS70592). The protein sequences of $L$. interrogans and E. coli ClpB were retrieved from UniProtKB (accession number Q72QU2 (CLPB_LEPIC)/http:// www.uniprot.org/uniprot/Q72QU2 and P63284 (CLPB_ECOLI)/ http:// www.uniprot.org/uniprot/P63284).

\section{Authors' contributions}

JK, ZA, DW performed the experiments. SKM designed the experiments, analyzed the data and drafted the manuscript. MZ assisted in data analyses and the preparation of manuscript. All authors read and approved the final manuscript.

\section{Competing interests}

The authors declare that they have no competing interests.

\section{Consent for publication}

Not applicable.

\section{Ethics approval and consent to participate}

The sera and kidney tissues used in this work were originally collected during another study (project license number PPL2608, date of approval 15 October 2008). All operators involved in the study, protocols, and premises were licensed under the Animals (Scientific Procedures) Act (1986) (ASPA).

\section{Author details}

'Department of General and Medical Biochemistry, University of Gdansk, Faculty of Biology, 80-308 Gdańsk, Poland. ${ }^{2}$ University Centre of Veterinary Medicine JU-UAK, University of Agriculture in Krakow, 30-059 Krakow, Poland. ${ }^{3}$ Departament of Biochemistry and Molecular Biophysics, Kansas State University, Manhattan, KS 66506, USA.

Received: 24 February 2016 Accepted: 12 July 2016

Published online: 16 July 2016

\section{References}

1. Adler B, Lo M, Seemann T, Murray GL. Pathogenesis of leptospirosis: the influence of genomics. Vet Mirobiol. 2011;153:3-81.

2. Cino M. New insights into the pathogenicity of leptospires: evasion of host defences. New Microbiol. 2010;33:283-92.

3. Ryan EG, Nola L, O'Grady L, More SJ, Doherty ML. Seroprevalence of Leptospira Hardjo in the irish suckler cattle population. Ir Vet J. 2012;65:8.
4. Arent Z, Kędzierska-Mieszkowska S. Seroprevalence study of leptospirosis in horses in northern Poland. Vet Rec. 2013;172:269.

5. Arent Z, Frizzell C, Gilmore C, Mackie D, Ellis WA. Isolation of leptospires from genital tract of sheep. Vet Rec. 2013;173:582.

6. Arent ZJ, Andrews S, Adamama-Moraitou K, Gilmore C, Pardali D, Ellis WA. Emergence of novel Leptospira serovars: a need for adjusting vaccination policies for dogs? Epidemiol Infect. 2013;141:1148-53.

7. Zolkiewski M. ClpB cooperates with DnaK, DnaJ, and GrpE in suppressing protein aggregation. J Biol Chem. 1999;274:28083-6.

8. Lourdault K, Cerqueira GM, Jr Wunder EA, Picardeau M. Inactivation of $\mathrm{clpB}$ in the pathogen Leptospira interrogans reduces virulence and resistance to stress conditions. Infect Immun. 2011;79:3711-7.

9. Havlasova J, Hemychowa L, Brechta M, Hubalek M, Lenco J, Larsson P, et al. Proteomic analysis of anti-Francisella tularensis LVS antibody response in murine model of tularemia. Proteomics. 2005:5:2090-103.

10. Kannan TR, Musatovova O, Gowda P, Baseman JB. Characterization of a unique ClpB protein of Mycoplasma pneumoniae and its impact on growth. Infect Immun. 2008;76:5082-92

11. WHO. Human Leptospirosis: Guidance for Diagnosis Surveillance and Control. 2003

12. Wolff JW. The laboratory diagnosis of leptospirosis. Publ. No. 183, American Lecture Series. Charles C. Thomas, Publisher, Springfield, Illinois, USA; 1954

13. Bradford MM. A rapid and sensitive method for quantition of proteins utilizing the principles of protein-dye binding. Anal Biochem. 1976;72:248-54.

14. Sambrook J, Fritsch EF, Maniatis T. Molecular cloning: a laboratory manual. New York: Cold Spring Harbor Laboratory Press; 1989.

15. Zhang T, Kedzierska-Mieszkowska S, Liu H, Cheng C, Ganta RR, Zolkiewski M. Aggregate-reactivation activity of the molecular chaperone ClpB from Ehrlichia chaffeensis. PLoS One. 2013. doi:10.1371/journal.pone.0062454.

16. Laemmli UK. Cleavage of the structural protein during assembly of the head of bacteriophage T4. Nature. 1970;227:680-5.

17. Harlow E, Lane D. Antibodies. A laboratory manual, CSH. New York: Cold Spring Harbor; 1988

18. Ferreria $H B$, de Castro LA. A preliminary survey of $M$. hyopneumoniae virulence factors based on comparative genomic analysis. Genet Mol Biol. 2007;30:245-55.

19. Amemiya K, Meyers JL, DeShazer D, Riggins RN, Halasohoris S, et al. Detection of the host immune response to Burkholderia mallei heat-shock proteins GroEL and DnaK in a glanders patient and infected mice. Diagn Microbiol Infect Dis. 2007;59:137-47.
Submit your next manuscript to BioMed Central and we will help you at every step:

- We accept pre-submission inquiries

- Our selector tool helps you to find the most relevant journal

- We provide round the clock customer support

- Convenient online submission

- Thorough peer review

- Inclusion in PubMed and all major indexing services

- Maximum visibility for your research

Submit your manuscript at www.biomedcentral.com/submit
) Biomed Central 